\begin{tabular}{|l|l|l||}
\hline \multicolumn{2}{|c|}{ PublisherInfo } \\
\hline \hline PublisherName & $:$ & BioMed Central \\
\hline \hline PublisherLocation & $:$ & London \\
\hline \hline PublisherImprintName & $:$ & BioMed Central \\
\hline \hline
\end{tabular}

\title{
Keeping a CHEK on breast cancer
}

\begin{tabular}{|l|c|l||}
\hline \multicolumn{2}{|c|}{ ArticleInfo } \\
\hline \hline ArticleID & $:$ & 4460 \\
\hline \hline ArticleDOI & $:$ & $10.1186 /$ gb-spotlight-20020424-02 \\
\hline \hline ArticleCitationID & $:$ & spotlight-20020424-02 \\
\hline \hline ArticleSequenceNumber & $:$ & 126 \\
\hline \hline ArticleCategory & $:$ & Research news \\
\hline ArticleFirstPage & $:$ & 1 \\
\hline \hline ArticleLastPage & $:$ & 2 \\
\hline \hline & & RegistrationDate : 2002-4-24 \\
\hline ArticleHistory & $:$ & OnlineDate \\
\hline \hline ArticleCopyright & $:$ & BioMed Central Ltd2002-4-24 \\
\hline \hline ArticleGrants & $:$ & \\
\hline \hline ArticleContext & $:$ & 130593311 \\
\hline \hline
\end{tabular}




\section{Jonathan B Weitzman}

Email: jonathanweitzman@hotmail.com

Mutations in the tumor suppressor genes BRCA1andBRCA2 account for a small percentage of breast cancer cases. In an Advanced Online Publication from Nature Genetics, researchers from the CHEKBreast Cancer Consortium report the identification of a mutation in the CHEK2 gene that increases the risk of breast cancer in both women and men (22 April 2002, DOI: 10.1038/ng879). They performed a genome-wide linkage search in a family with $B R C A$-independent breast cancer and identified a mutation in the CHEK2 gene that results in a truncated protein. CHEK2 is a cell-cycle checkpoint kinase involved in DNA-damage-response pathways. The mutation abolished kinase activity, and is five times more frequent in families affected by breast cancer who do not have BRCA1 or BRCA2 mutations.

\section{References}

1. Genetic heterogeneity and penetrance analysis of the $B R C A 1$ and $B R C A 2$ genes in breast cancer families.

2. Nature Genetics, [http://genetics.nature.com]

3. The human homologs of checkpoint kinases Chk1 and Cds1 (Chk2) phosphorylate p53 at multiple DNA damage-inducible sites. 